\title{
Liver-Mediated Adaptive Immune Tolerance
}

\begin{abstract}
Meijuan Zheng ${ }^{1}$ and Zhigang Tian ${ }^{2,3 *}$
${ }^{1}$ Department of Clinical Laboratory, First Affiliated Hospital of Anhui Medical University, Hefei, China, ${ }^{2}$ Hefei National Laboratory for Physical Sciences at Microscale, CAS Key Laboratory of Innate Immunity and Chronic Disease, Division of Molecular Medicine, School of Life Sciences, University of Science and Technology of China, Hefei, China, ${ }^{3}$ Institute of Immunology, University of Science and Technology of China, Hefei, China
\end{abstract}

The liver is an immunologically tolerant organ that is uniquely equipped to limit hypersensitivity to food-derived antigens and bacterial products through the portal vein and can feasibly accept liver allografts. The adaptive immune response is a major branch of the immune system that induces organ/tissue-localized and systematic responses against pathogens and tumors while promoting self-tolerance. Persistent infection of the liver with a virus or other pathogen typically results in tolerance, which is a key feature of the liver. The liver's immunosuppressive microenvironment means that hepatic adaptive immune cells become readily tolerogenic, promoting the death of effector cells and the "education" of regulatory cells. The above mechanisms may result in the clonal deletion, exhaustion, or inhibition of peripheral T cells, which are key players in the adaptive immune response. These tolerance mechanisms are believed to be responsible for almost all liver diseases. However, optimal protective adaptive immune responses may be achieved through checkpoint immunotherapy and the modulation of hepatic innate immune cells in the host. In this review, we focus on the mechanisms involved in hepatic adaptive immune tolerance, the liver diseases caused thereby, and the therapeutic strategies needed to overcome this tolerance.

Keywords: liver tolerance, $\mathrm{T}$ cell dysfunction, innate cell dysfunction, immune regulation, liver-draining lymph node, liver diseases

\section{INTRODUCTION}

As the largest organ in the body, the liver has a rich circulatory supply, receiving blood from both the hepatic artery and the portal vein. As a result, the liver comes into contact with a large proportion of microbial products, as well as harmless food-derived antigens, via the intestines. A high level of exposure to these antigens endows the liver with a distinctive form of immune privilege. This so-called immunotolerance ensures that the liver does not mount a strong immune response against gastrointestinal tract-derived molecules and pathogens. This tolerance effect is also evidenced by the fact that the liver readily accepts allografts, despite a major histocompatibility complex (MHC) mismatch, as seen early on in the pig model of transplantation (1).

Later studies have shown that the liver can accept subsequent non-hepatic allografts from the same donor by inducing systemic immune tolerance (2). Similarly, the tolerance induced via the liver-mediated expression of exogenous proteins is used in gene therapy for hemophilia, metabolic disorders, lysosomal storage disorders (3), and even autoimmune diseases (4). However, the hepatic immune tolerogenic environment is also exploited by hepatitis viruses, parasites, and tumors and can lead to persistent infection and rapid cancer progression. 
Adaptive immunity plays a key role in defending the host against pathogens and tumors. The liver determines organ/tissue-localized and systematic adaptive immune responses, highlighting the link between adaptive immune responses and the hepatic microenvironment (5). Evidence also suggests that relationships exist between adaptive immune responses and the hepatic tolerogenic microenvironment (6). This tolerogenic microenvironment leads to liver $\mathrm{T}$ cell dysfunction, including clonal deletion, anergy, senescence, deviation, and exhaustion. The liver is home to large numbers of hepatocytes, nonparenchymal cells, and lymphocytes (7). This means that complex interactions between these cells contribute to the induction of adaptive immune tolerance in the liver. For example, parenchymal and nonparenchymal cells suppress the adaptive immune response, leading to hepatic $\mathrm{T}$ cell dysfunction, partially as a result of inhibitory receptor and anti-inflammatory cytokine expression (8).

Here, we describe hepatic adaptive immune cell-related dysfunction in the context of liver-mediated adaptive immune tolerance. We focused on: (i) $\mathrm{T}$ cell dysfunction, including anergy, exhaustion, and apoptosis, (ii) the regulatory mechanisms involved in the induction of $\mathrm{T}$ cell dysfunction, (iii) the current understanding of the role of $\mathrm{T}$ cell dysfunction in liver disease, and (iv) the therapeutic strategies developed to counteract adaptive immune tolerance, to illustrate the complexity of and challenges related to liver-mediated adaptive immune tolerance.

\section{THE ADAPTIVE IMMUNE TOLERANCE MECHANISMS}

How does the liver tolerize adaptive immune cells? Since adaptive immune cells are easier to render tolerant in the liver than in other organs, the liver has been classically referred to as a "graveyard" for effector T cells and a "school" for regulating cells. In this regard, several reports demonstrate that local antigen presentation in the liver results in T cell apoptosis $(9,10)$.

\section{The Liver Acts as a T Cell "Graveyard"}

The classic hypothesis that the liver functions as a "graveyard" for $\mathrm{T}$ cells suggests that the liver represents a specific site for the apoptosis of activated T cells (11) that become trapped and eventually destroyed in the liver by clonal deletion, clonal anergy, clonal deviation, and $\mathrm{T}$ cell exhaustion.

Clonal deletion is a process whereby $\mathrm{T}$ and $\mathrm{B}$ cells expressing antigen-specific receptors with self-reactive specificities are deleted during their development. Huang and colleagues used $\mathrm{T}$ cell receptor (TCR) transgenic mice to show that activated $\mathrm{T}$ cells could be programmed to undergo apoptosis in the liver through peptide injection (12). Another study suggested that the

\footnotetext{
Abbreviations: TCR, T cell receptor; LSECs, Liver sinusoidal endothelial cells; pDCs, Plasmacytoid dendritic cells; LCMV, Lymphocytic choriomeningitis virus; HCV, Hepatitis C virus; APCs, Antigen presenting cells; HSCs, Hepatic stellate cells; MHC, Major histocompatibility complex; Tregs, Regulatory T cells; NKT, Natural killer T; HBV, Hepatitis B virus; LNs, Lymph nodes; HCC, Hepatocellular carcinoma; (m)DCs, Myeloid; iMATEs, Intrahepatic myeloid-cell aggregates for T cell expansion.
}

liver trapped and passively sequestered activated $\mathrm{CD} 8^{+} \mathrm{T}$ cells (13). In line with these findings, another transgenic mouse model indicated that hepatocyte-activated $\mathrm{CD} 8^{+} \mathrm{T}$ cells with increased expression of Bim were associated with premature death (14). A landmark study by the Bertolino group demonstrated that $\mathrm{CD}^{+} \mathrm{T}$ cells undergoing emperipolesis were endocytosed and deleted by hepatocytes, suggesting that "suicidal emperipolesis" is a unique mechanism of peripheral deletion (15). Thus, this "suicidal emperipolesis" plays an important role in liver-activated autoreactive $\mathrm{CD}^{+} \mathrm{T}$ cell clearance and immune homeostasis in the liver (16).

Clonal anergy refers to a state of inactivation experienced by self-reactive lymphocytes. Anergic lymphocytes cannot induce strong immunity in healthy individuals. Liver sinusoidal endothelial cells (LSECs), acting as antigen-presenting cells, in the absence of accessory signals reportedly induce anergy in $\mathrm{T}$ cells within the hepatic microenvironment (17). Another study supports the idea that plasmacytoid dendritic cells (pDCs) may also lead to the inhibition of $\mathrm{T}$ cell activity in the liver, resulting in the anergy or deletion of antigen-specific T cells (18).

Clonal deviation is the process whereby naïve $\mathrm{CD} 4^{+} \mathrm{T}$ cells preferentially assume the Th2 but not the Th1 or the Th17 phenotype during differentiation in the liver. The priming of naïve $\mathrm{CD} 4^{+} \mathrm{T}$ cells by liver sinusoidal endothelial cells (LSECs) fails to promote their differentiation into Th1 cells, even with the exogenous administration of the cytokines IL-1 $\beta$, IL-12, and IL18 (19). Thus, LSECs suppress the IFN- $\gamma$-producing Th1 cells in favor of the IL-4-expressing Th2 cells, contributing to the process of immune T cell deviation in the liver (20).

Another form of $\mathrm{T}$ cell dysfunction, $\mathrm{T}$ cell exhaustion, is often associated with chronic infection and tumorigenesis (21). An exhausted $\mathrm{T}$ cell is characterized by impaired effector functions and proliferative capacity, as well as altered transcriptional, epigenetic, and metabolic signatures, including the overexpression of inhibitory receptors and a dysregulated cytokine milieu $(22,23)$. The first report of $\mathrm{T}$ cell exhaustion occurred in a mouse model of noncytopathic lymphocytic choriomeningitis virus (LCMV) infection, in which exhausted $\mathrm{CD}^{+} \mathrm{T}$ cells displayed impaired effector functions compared to functional $\mathrm{CD}^{+} \mathrm{T}$ cells (24). This begs the question of what causes $\mathrm{T}$ cell exhaustion in the first place.

Firstly, persistently high levels of antigen contribute to $\mathrm{T}$ cell exhaustion (25). A threshold of intrahepatic antigen levels tunes the fate of cytotoxic $\mathrm{T}$ lymphocyte (CTL) function, and high levels of antigen maintain an exhausted $\mathrm{T}$ cell phenotype (26). Secondly, altered inflammatory and tissue microenvironments play an important role in inducing $\mathrm{T}$ cell tolerance (22). In such circumstances, $\mathrm{T}$ cells lose their robust effector functions, accompanied by an increase in the expression of multiple inhibitory receptors, such as PD-1, CTLA-4, LAG-3, and TIM-3.

In addition, $\mathrm{T}$ cells receive inhibitory signals from various immunosuppressive cytokines. The phenomenon of $\mathrm{T}$ cell exhaustion has been reported both in chronic infections and cancer of the liver. Exhausted hepatic $\mathrm{T}$ cells are closely related to inefficient clearance of persisting pathogens and tumorigenesis in chronic liver diseases, including hepatitis 
$\mathrm{B}$ and C, malaria, schistosomiasis, and liver cancers. Thus, $\mathrm{T}$ cell exhaustion is considered to be associated with hepatic tolerogenic characteristics in liver diseases. Recently, the signal-regulatory protein $\alpha$ was shown to act as an inhibitory receptor when expressed on $\mathrm{CD}^{+} \mathrm{T}$ cells during chronic exhaustion in chronic hepatitis $\mathrm{C}$ virus (HCV) infection (27).

\section{The Liver Acts as a School to Educate T Cells}

The coordination between innate and adaptive immune cells often occurs when confronting liver disease, as the unique structure of this organ facilitates interactions between these cells. There are several hepatic antigen presenting cells (APCs) including resident hepatocytes and non-parenchymal cells like DCs, LSECs, Kupffer cells, and hepatic stellate cells (HSCs) involved in antigen presentation, which facilitate adaptive immune tolerance in the liver (28). During the induction of liver immune tolerance, cytokines like IL-10, TGF- $\beta$, and IFN- $\gamma$ are thought to be involved in the development of chronic liver disease and $\mathrm{T}$ cell dysfunction (29-31). In the liver environment, multiple factors, including APCs, the site of primary $\mathrm{T}$ cell activation, and altered inflammation, dictate the immune outcomes of intrahepatic T cells $(32,33)$.

Hepatocytes, which do not normally express MHC class II molecules, acquire the ability to express MHC II and activate $\mathrm{CD}^{+} \mathrm{T}$ cells during hepatitis (34). Under specific circumstances, however, antigen presentation by hepatocytes can promote immune tolerance. For instance, MHC II-expressing hepatocytes seem to be associated with defective $\mathrm{CD}^{+}$and $\mathrm{CD}^{+} \mathrm{T}$ cell function and higher LCMV titers in class II transactivator molecule (CIITA)-transgenic mice compared with nontransgenic mice (35). Furthermore, the adeno-associated viral vector-mediated expression of a single MHC I allele in hepatocytes induced tolerance toward an allogeneic graft in a transfer experiment involving liver-generated $\mathrm{CD} 8^{+}$regulatory T cells (Tregs) (36).

A recent study showed that Qa-1 expression in hepatocytes with $\mathrm{NKG}_{2} \mathrm{~A}^{+}$natural killer $(\mathrm{NK})$ cells induced $\mathrm{CD}^{+} \mathrm{T}$ cell exhaustion and persistent $\mathrm{HCV}$ infection in humanized $\mathrm{C} / \mathrm{O}^{\mathrm{Tg}}$ mice (37). Interestingly, hepatocytes are also capable of converting $\mathrm{CD}^{+}{ }^{+} \mathrm{T}$ cells into Foxp $3^{+}$Tregs in vitro, resulting in the Treg-mediated suppression of the $\mathrm{CD} 4^{+} \mathrm{T}$ cell response via the Notch signaling pathway (38). Together, these observations indicate that hepatocytes mediate $\mathrm{T}$ cell dysfunction in the liver.

The DCs are professional antigen-presenting cells (APCs) that migrate to the draining lymph node and present antigens to $\mathrm{T}$ cells $(39,40)$. Hepatic DCs exhibit an immature phenotype, thus maintaining liver tolerance (41). More importantly, tolerogenic DCs, associated with low MHC class I and II levels and a high expression of $\mathrm{T}$ cell coinhibitory ligands, mediate tolerogenic effects, including $\mathrm{T}$ cell deletion, anergy, Th2 polarization, and the induction of Tregs (42). Tolerogenic DCs also show considerable promise in the control of autoimmune diseases and allograft rejection $(43,44)$ by promoting tolerance within the hepatic microenvironment. Liver DCs secrete IL-10 and are associated with reduced $\mathrm{T}$ cell proliferation and function compared to blood DCs (45).

Kupffer cells account for the largest population of macrophages in the liver. Under many circumstances, Kupffer cells play an important role in antigen uptake and pathogen clearance. However, during homeostasis, Kupffer cells secrete anti-inflammatory soluble factors, such as IL-10, to maintain hepatic tolerance $(46,47)$. In addition, Kupffer cells reportedly mediate $\mathrm{T}$ cell suppression, without the need for cytokines like IL-10, TGF- $\beta$, and nitric oxide (48).

The hepatic stellate cells (HSCs) and LSECs are wellcharacterized liver-resident APCs that are capable of tolerizing T cells. For example, TGF- $\beta 1$ produced by HSCs inhibits $\mathrm{T}$ cells via glycoprotein A repetitions predominant (GARP)dependent expression on HSCs (49). Moreover, the expression of $\mathrm{B} 7-\mathrm{H} 1$ on HSCs contributes to the regulation of $\mathrm{T}$ cell responses by promoting their apoptosis (50). Within the hepatic microenvironment, LSECs can also tolerize both $\mathrm{CD}^{+}$and $\mathrm{CD}^{+} \mathrm{T}$ cells. Furthermore, while LSECs can prime $\mathrm{CD} 4^{+} \mathrm{T}$ cells, these $\mathrm{CD} 4^{+} \mathrm{T}$ cells do not acquire a Th1 phenotype (19). Antigen cross-presentation by LSECs to $\mathrm{CD} 8^{+} \mathrm{T}$ cells also leads to tolerance rather than $\mathrm{CD}^{+} \mathrm{T}$ cell activation (51).

The NK cells, which belong to a major group of innate immune cells in the liver, contribute to host defense against virally infected cells and tumors. Mice reportedly contain two liver NK cell subsets, which are referred to as conventional NK cells (which enter the circulation) and tissue-resident NK cells $(52,53)$. The markers CD49a and DX5 can be used to subdivide murine NK cells into conventional (CD49a $\left.{ }^{+} \mathrm{DX} 5-\right)$ and liverresident (CD49a-DX5 ${ }^{+}$) NK cells (54). Similarly, human livers are also populated with two overlapping NK cell subsets (55).

Generally, NK cell function is controlled by a diverse set of activating and inhibitory receptors, the balance between which also contributes to the regulation of $\mathrm{T}$ cells $(56,57)$. For example, hepatic conventional NK cells contribute to effective antihepatitis B virus (HBV) T cell responses, while liver-resident NK cells directly suppress $\mathrm{T}$ cell responses through the programmed cell death-1 ligand-receptor (PDL1-PD1) axis $(58,59)$. Impaired $\mathrm{NK}$ cell function is accompanied by weakened cytotoxic $\mathrm{CD} 8^{+} \mathrm{T}$ cell activity in persistent viral infections (60). Indirectly, NK cells also diminish $\mathrm{CD}^{+} \mathrm{T}$ cell responses during chronic infection by interacting with DCs (61).

Interestingly, the hepatic NK cell-associated modulation of the effector $\mathrm{T}$ cell response is, in turn, regulated by the liver microenvironment, such as the presence of IL-10 (62). In addition, HBV-specific $\mathrm{CD}^{+} \mathrm{T}$ cells become susceptible to TNF-related apoptosis-inducing ligand (TRAIL)-expressing NK cell-mediated killing by upregulated TRAIL-R2 expression in patients with chronic $\mathrm{HBV}$ infection $(\mathrm{CHB})$, indicating that $\mathrm{NK}$ cells downregulate $\mathrm{HBV}$-specific $\mathrm{CD}^{+} \mathrm{T}$ cell responses $(63,64)$. In this scenario, upon TRAIL and NKG2D blockade, NK cell-mediated HBV-specific T cell function is also enhanced in patients with $\mathrm{CHB}$ who are treated with a nucleos(t)ide $\operatorname{analog}(65)$.

Also residing in the liver are natural killer $\mathrm{T}$ (NKT) cells, innate-like $\mathrm{T}$ cells that modulate the hepatic immune response by producing pro- and anti-inflammatory cytokines upon 
activation. There are two types of NKT cells, type I and type II NKT cells. Type I NKT cells express a semi-invariant TCR and is also referred to as invariant (i) NKT cells. By contrast, type II NKT cells express a relatively diverse TCR repertoire. Type II NKT cells conversely appear to be more abundant than type I NKT cells in humans, but in liver diseases, they are similar to type I NKT cells in phenotype and function (66).

By bridging the innate and adaptive responses, NKT cells act as immunoregulators during immunological liver disease. Lan et al. (67) revealed that the pyroptosis of iNKT cells through OX40 signaling can lead to liver inflammation and damage, suggesting that NKT cells play an important role in liver homeostasis. On the other hand, activated NKT cells contribute to the recruitment of Tregs via the CXCR3-CXCL10 pathway (68). The NKT cells also reportedly promote the priming of IL10-producing $\mathrm{CD}^{+} \mathrm{T}$ cells by hepatocytes in order to limit liver injury (69).

Similar to NKT cells, mucosal-associated invariant T (MAIT) cells are the $\mathrm{T}$ cell subpopulation restricted to the MHCI-related (MRI) molecule MRI populated in humans that produces a Th1 and Th17 cytokine milieu (70). The presence of highly enriched MAIT cells in the human liver suggests the importance of these innate cells in the control of liver infections $(71,72)$. However, in patients with chronic $\mathrm{HCV}$ infections, $\mathrm{CD} 8^{+} \mathrm{CD} 161^{++} \mathrm{TCRVa} 7.2^{+}$MAIT cells exhibit exhausted features, thereby contributing to $\mathrm{HCV}$ persistence (73). In line with these findings, MAIT cells from patients with chronic hepatitis delta virus (HDV) are functionally impaired and subsequently lost during HDV infection (74). In patients with hepatocellular carcinoma (HCC), tumor-educated MAIT cells upregulate inhibitory receptors and display functional impairment, both of which correlate with HCC progression (75).

The Tregs negatively regulate effective $\mathrm{T}$ cell immune responses via the production of immunosuppressive cytokines (including IL-10 and TGF- $\beta$ ) during chronic infection and are considered to be a potential target for the treatment of patients with CHB (7). Through upregulated Tregs, IL-33 exerts a negative effect on $\mathrm{CD}^{+} \mathrm{T}$ cell proliferation and alleviates hepatitis (76). Similarly, it was found that Tregs orchestrate $\mathrm{CD} 8^{+} \mathrm{T}$ cell exhaustion by engaging the PD- 1 inhibitory pathway during LCMV infection (77). However, circulating $\mathrm{CD}^{+} \mathrm{CD} 25^{+}$ regulatory $\mathrm{T}$ cells exist in patients with resolved $\mathrm{HBV}$ infection (78). Furthermore, the numbers of these regulatory cells are increased and correlate with hepatic inflammation in patients with hepatitis B (79). Therefore, Tregs might play a role in anti-inflammatory activity and need to be more thoroughly assessed (80).

In contrast to $\mathrm{T}$ cell tolerance, antibody response to $\mathrm{HBV}$ proteins does not provide evidence for $\mathrm{B}$ cell tolerance during HBV infection. For example, antibodies specific to the HBV core antigen (anti- $\mathrm{HBc}$ ) are clearly detectable during acute $\mathrm{HBV}$ infection (81). Interestingly, anti- $\mathrm{HBc}$ antibodies can be elicited in patients with $\mathrm{CHB}$ and are more abundant in $\mathrm{CHB}$ infection compared with in patients with self-limited infections $(82,83)$. Furthermore, highly active B cell responses are indicated during chronic $\mathrm{HBV}$ infection through gene expression profiling (84). In contrast, hepatitis B surface antibodies (anti-HBs) are considered to be protective and are commonly associated with viral control and the resolution of clinical disease. A recent study demonstrated that $\mathrm{HBcAg}$-specific $\mathrm{B}$ cells and HBsAg-specific B cells were different in phenotype and function but shared an increased mRNA expression of genes linked with the role of cross-presentation and innate immunity in patients with CHB (85). Overall, the above results indicate that HBVspecific humoral responses are apparently not suppressed in the liver.

\section{The Role of Liver-Draining Lymph Nodes (LNs) in the Induction of Hepatic Immune Tolerance}

Although the "graveyard" and "school" models are adequate under certain circumstances, some argue that $\mathrm{T}$ cell tolerance is not the direct consequence of local antigen-presentation (86), and that the "graveyard" theory cannot account for the existence of efficient immune responses under different conditions (87). Since many other factors are involved, the two models may not present full explanations of the tolerogenic mechanisms at play in the liver, and additional hypotheses may be required.

The liver produces considerable amounts of lymphatic fluid, which is one of the two major sources of abdominal lymph. Hepatic lymph is thought to originate from the filtration of the sinusoids into the space of Disse, even before the lymph drains from the liver through the lymphatic vessels to the draining LN (88). Although the liver-draining LNs are well-reported in humans, the portal and celiac liver-draining LNs in the mouse have only recently been clearly described in studies that used Evans blue dye or infection with an adenovirus vector carrying the enhanced green fluorescent protein gene (Ad-EGFP) to track hepatic lymphatic draining $(89,90)$. These studies also show that DCs exit the liver and migrate to the liver-draining LNs, where they prime and facilitate specific $T$ cell responses.

Interestingly, portal and celiac LNs appear to be independent liver-draining LNs, with different cellular compositions and modes of organogenesis. Furthermore, the portal LN participates in oral tolerance via Treg induction, while the celiac LN facilitates effective $\mathrm{T}$ cell responses (91). The immune response that occurs in liver-draining LNs is associated with the liver microenvironment, which is considerably different from that of the spleen. Importantly, liver-draining LNs are implicated in chronic human disease $(92,93)$. Recent progress in research studies related to the association between the liver and human portal LNs indicates that a paucity of DCs in human portal LNs contributes to hepatic immune tolerance (94). In addition, the regional immunity implicated in liver homeostasis and disease is associated with tissue-specific immune cell subsets and their interactions with the liver (7). Thus, a major aspect of liver function is dependent on specific hepatic immune cell subsets, which may, in turn, be influenced by the immune responses modulated by liver-draining LNs.

Moreover, studies indicate that liver inflammation is also involved in liver tolerance. Patients with chronic hepatitis B have fewer signs of inflammation than those with acute hepatitis B who clear the viral infection and display significant inflammation (95). 
Furthermore, circulating monocytes under inflammatory stimuli can activate autologous HBV-specific T cells during chronic HBV infection, suggesting that inflammatory conditions might have an impact on intrahepatic HBV-specific T cells $(80,96)$.

In a study conducted in chimpanzees with chronic infections, agonists of toll-like receptor (TLR) 7 activated TLR-7 signaling and reversed immune tolerance associated with significant intrahepatic inflammation (97). Similarly, TLR 7 agonists appear to enhance $\mathrm{T}$ cell and $\mathrm{NK}$ cell activities in patients with $\mathrm{CHB}$ who are subjected to nucleos(t)ide therapy (98). The above results, taken together, support the hypothesis that inflammatory events in the liver might alter the features of liver tolerance. However, liver tolerance is not absolute during viral hepatitis infection. For example, patients with acute hepatitis elicit an effective adaptive immune response but lack immune tolerance to hepatitis $\mathrm{A}, \mathrm{B}$, and C (99-101).

In summary, several mechanisms are involved in the induction of $\mathrm{T}$ cell dysfunction in the liver. On the one hand, the liver is seen as a "graveyard" or killing field for activated $\mathrm{T}$ cells, because it can induce $\mathrm{T}$ cell dysfunction in the local microenvironment. On the other hand, the large population of liver APCs, and cytokines like IL-10, TGF- $\beta$, and IFN$\gamma$ lead to the negative regulation and further dysfunction of $\mathrm{T}$ cells. Additionally, the celiac and portal liver-draining LNs apparently play key roles in promoting liver-mediated adaptive immune tolerance through the induction of Tregs and paucity of DCs. Moreover, a lack of inflammatory events under certain circumstances is also associated with $\mathrm{T}$ cell dysfunction (Figure 1).

\section{ADAPTIVE IMMUNE TOLERANCE IN LIVER DISEASE}

Under certain pathological circumstances, pathogens, including HBV, HCV, malaria, and schistosomes, exploit the liver's tolerogenic mechanisms to establish persistent infections. For the same reason, the hepatic immunotolerant microenvironment further facilitates the progression of chronic infection to liver fibrosis, cirrhosis, and cancer. Based on the mechanisms involved in liver tolerance, the presence of dysfunctional adaptive immune cells and immunosuppressive regulatory cells is a hallmark of chronic liver disease, including chronic infections and HCC.

\section{Chronic Liver Infection}

Effective $\mathrm{T}$ cell responses mediate viral clearance in murine models of HBV infection (58). Intrahepatic HBV-specific $\mathrm{CD}^{+}$ $\mathrm{T}$ cells contribute to viral elimination and disease pathogenesis in chimpanzees acutely infected with HBV (102). Similarly, patients with acute HBV infection reportedly have enhanced $\mathrm{HBV}$-specific $\mathrm{CD}^{+} \mathrm{T}$ cell responses, which are associated with viral control $(103,104)$.

Conversely, patients with chronic HBV exhibit HBV-specific $\mathrm{CD}^{+} \mathrm{T}$ cell dysfunction, with increased frequencies and intensities of PD-1 expression (105). These findings were reported in the first study to show that $\mathrm{HBV}$-specific $\mathrm{CD} 8^{+} \mathrm{T}$ cells in humans can be exhausted. A recent study using peptide-loaded MHC I tetramers suggests that the phenotypic and functional differences of $\mathrm{HBV}$-specific $\mathrm{CD} 8^{+} \mathrm{T}$ cells can be detected by targeting core vs. polymerase antigen epitopes in patients with $\mathrm{CHB}$, indicating that the molecular mechanisms underlying dysfunctional $\mathrm{CD}^{+} \mathrm{T}$ cell populations are not homogeneous in patients with $\mathrm{CHB}$ patients (106).

Intrahepatic $\mathrm{HCV}$-specific $\mathrm{CD}^{+} \mathrm{T}$ cells have an impaired ability to produce IFN- $\gamma$, resulting in a failure to control $\mathrm{HCV}$ infection in patients in whom the infection is chronic (107). In addition, it is found that HBV clearance can be achieved by the reconstitution of HBV-specific $\mathrm{CD}^{+} \mathrm{T}$ cells, thereby reestablishing adaptive immune responses and reversing HBV-specific tolerance (108). The upregulation of inhibitory receptors on $\mathrm{T}$ cells in chronic infection is indicative of $\mathrm{T}$ cell exhaustion during viral persistence. For instance, $\mathrm{T}$ cell dysfunction is associated with the increased expression of PD-1 and CTLA-4 in patients with CHB compared with in healthy controls (109). Furthermore, in chronic HCV infection, $\mathrm{HCV}$-specific $\mathrm{CD}^{+} \mathrm{T}$ cell exhaustion is associated with high expression of inhibitory receptors, while the population of PD-1-TIM-3- HCV-specific CD8 ${ }^{+} \mathrm{T}$ cells outnumbers the frequency of $\mathrm{PD}-1^{+} \mathrm{TIM}-3^{+} \mathrm{T}$ cells in acute resolving $\mathrm{HCV}$ infection (110).

Regarding parasitic infections, malaria, and schistosomiasis also establish pathogen persistence and liver tolerance. The $\mathrm{CD}^{+} \mathrm{T}$ cells generated in the liver fail to eliminate malariacausing sporozoites owing to hepatic immune tolerance (111). Moreover, the poor effector functions of exhausted parasitespecific $\mathrm{T}$ cells during malaria infection are also linked to PD-1 expression (112). During hepatic schistosomiasis, Th2 cells and Tregs dominate the immune response and release immunosuppressive cytokines, including IL-10 and TGF- $\beta$ in the liver $(113,114)$. In addition, many other factors, including the ligands of inhibitory receptors expressed on APCs, account for the failure of dysfunctional $\mathrm{T}$ cells to eliminate pathogenic infections in the liver. For example, owing to the selective overexpression of PD-L1 on the surface of macrophages, both $\mathrm{CD}^{+}{ }^{+} \mathrm{T}$ and $\mathrm{CD} 8{ }^{+} \mathrm{T}$ cells become anergized by the Schistosoma mansoni parasite (115).

\section{Liver Cancer}

Antigen-specific $\mathrm{T}$ cells play a key role in controlling cancer, but similar to chronic viral infections, persistent tumor cell stimulation causes $\mathrm{T}$ cell exhaustion (25). A single $\mathrm{T}$ cell database revealed that exhausted tumor-infiltrating $\mathrm{CD} 8^{+} \mathrm{T}$ cells preferentially accumulate in the HCC tumor microenvironment (116). In addition, the epigenetic profile of exhausted $\mathrm{T}$ cells is distinct from that of functional effector and memory $\mathrm{T}$ cells (117). In the context of the tumor microenvironment, exhausted $\mathrm{CD}^{+} \mathrm{T}$ cells exhibit reduced effector functions and proliferative capacity. Furthermore, in HCC tissue, $\mathrm{CD}^{+}$and $\mathrm{CD} 8^{+} \mathrm{T}$ cells display increased expression of inhibitory receptors such as PD-1, TIM-3, LAG-3, and CTLA-4 (118).

Moreover, HCC specimens reportedly harbor exhausted $\mathrm{CD}^{+} \mathrm{T}$ cells with varying levels of PD-1 expression. The PD$1^{\text {High }} \mathrm{CD}^{+} \mathrm{T}$ cell subset co-expresses high levels of TIM-3 and LAG-3, as is characterized by low IFN- $\gamma$ and TNF production, indicating that the expression of $\mathrm{PD}-1$ on $\mathrm{CD}^{+} \mathrm{T}$ cells arises as a result of the HCC microenvironment (119). A previous 


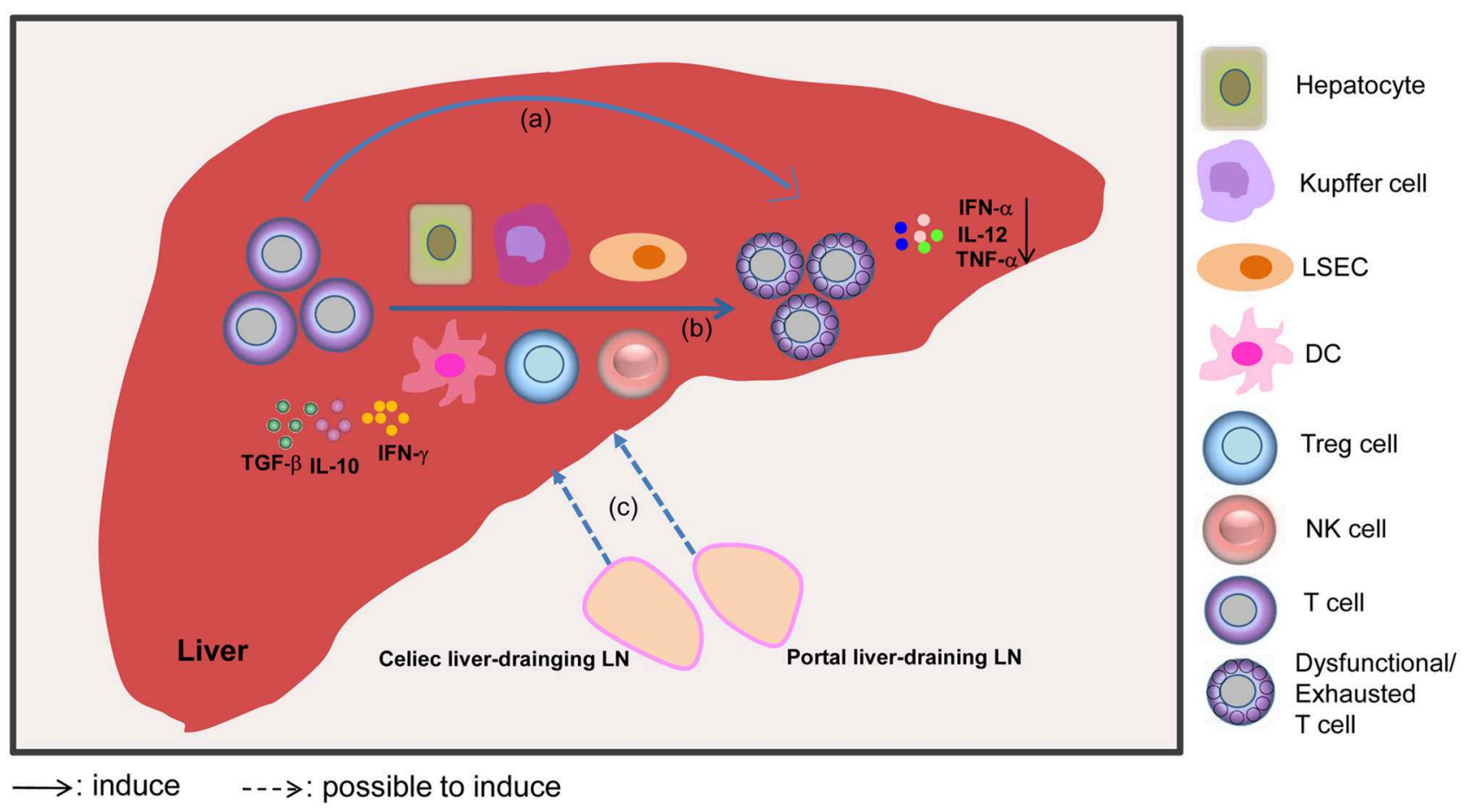

FIGURE 1 | Mechanisms involved in liver-mediated adaptive immune tolerance. The diagram outlines that the liver acts as a "graveyard" or killing field for activated T cells, leading to the apoptosis of activated T cells through clonal deletion, clonal anergy, clonal deviation, or exhaustion (a). Alternatively, the liver can act as a school to educate T cells, which means that T cells can be subjected to regulation by liver APCs, including dendritic cells (DCs), hepatocytes, Kupffer cells, liver sinusoidal endothelial cells (LSECs), regulatory T cells (Tregs), and NK cells, and cytokines like IL-10, TGF- $\beta$, and IFN- $\gamma$, which promote T cell dysfunction (b). Furthermore, dysfunctional T cells may be induced by the liver-draining $L N$ environment through antigen presentation. The liver-draining portal and celiac lymph nodes ( $L N s)$ play an important role in regulating hepatic immune tolerance (c). Moreover, mild or absent signs of liver inflammation, as evidenced by reduced levels of IFN- $\alpha$, IL-12, and TNF- $\alpha$ cytokines, are also associated with the scenario of liver tolerance.

study has shown that the upregulation of Lnc-TIM-3, which specifically binds to TIM-3, can result in $\mathrm{CD} 8^{+} \mathrm{T}$ cell exhaustion in HCC (120). During chronic liver diseases, $\mathrm{CD}^{+} \mathrm{T}$ cells with upregulated TIM-3 expression contribute to $\mathrm{CD}^{+} \mathrm{T}$ cell exhaustion. The membrane-bound TIM-3 can be cleaved from the cell membrane and yield serum soluble TIM-3, which is associated with liver dysfunction in patients with HCC (121).

Professional or conventional APCs, which can negatively affect $\mathrm{T}$ cell function, also play important roles in the regulation of the immune response. Recently, myeloid (m)DCs were found to be functionally impaired in patients with HCC (122), while PD-1 expression on mDCs contributed to the inhibition of $\mathrm{CD}^{+}$ $\mathrm{T}$ cell function (123). Kupffer cells also mediate the suppression of $\mathrm{CD}^{+} \mathrm{T}$ cells in human HCC, via the B7-H1/PD-1 axis, whereby tumor-associated IL-10 production contributes to the increased B7-H1 expression on Kupffer cells (124).

An important subset of innate immune cells, dysfunctional NK cells are also associated with tumor development (125) and are implicated in the development of HCC. For example, the high expression of NKG2A on NK cells contributes to $\mathrm{NK}$ cell exhaustion, which correlates with a poor prognosis for patients with HCC (126). Similarly to $\mathrm{NKG}_{2} \mathrm{~A}^{+} \mathrm{NK}$ cells, the HCC microenvironment harbors high numbers of functionally exhausted $\mathrm{CD}^{+} 6^{+} \mathrm{NK}$ cells and a few functionally active $\mathrm{CD} 160^{+} \mathrm{NK}$ cells in patients with HCC $(127,128)$.

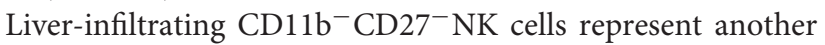
dysfunctional subset, closely associated with HCC progression (129). In line with the above findings, dysfunctional DCs, Kupffer cells, and NK cells are associated with T cell dysfunction in the HCC microenvironment. Further study is required to delineate the molecular mechanisms involved in the induction of $\mathrm{T}$ cell dysfunction, since the heterogeneity of various innate immune cell phenotypes and functions have been well-described.

\section{STRATEGIES FOR REVERSING T CELL DYSFUNCTION IN LIVER DISEASE}

In the liver, $\mathrm{T}$ cell-mediated immune tolerance is associated with chronic liver disease. Therefore, reversing immunotolerance is thought to be an effective strategy for restoring effective $\mathrm{T}$ cell function, and several approaches have been proposed. For example, novel T cell-based vaccines counteract $\mathrm{T}$ cell anergy and restore normal $\mathrm{CD}^{+} \mathrm{T}$ cell function, contributing to therapeutic immunity in chronic infection (130). A promising report showed that human redirected $\mathrm{T}$ cells with $\mathrm{HBV}$-specific TCR can induce antiviral effects in HBV-infected human liver chimeric 
mice (131). Furthermore, TCR-redirected T cells exhibited the potential for functional degranulation and reduced HBsAg levels in a patient with HBV-related HCC (132).

Interestingly, clinical evidence supports the theory that leukemia recipients with $\mathrm{HBV}$ infection undergoing bone marrow transplantation can be cured of functional HBV after bone marrow transfer from naturally HBV-immune or actively immunized donors $(133,134)$. Using IL-12-based vaccination to counteract liver-induced immunotolerance is also an effective strategy for eliciting robust $\mathrm{HBV}$-specific $\mathrm{T}$ cell immunity in an HBV-carrier mouse model (135). Moreover, the blockade of inhibitory signaling pathways to reinvigorate exhausted $\mathrm{T}$ cell immune responses is thought to be a promising therapeutic strategy, with the blockade of PD-1 signaling proving the most effective to date in the context of $\mathrm{HBV}$ infection (136). Notably, IL-12, as the third signal cytokine, enhances the ability of PD-1 signaling blockade to promote the recovery of functional $\mathrm{HBV}$-specific $\mathrm{CD} 8^{+} \mathrm{T}$ cells in patients with chronic HBV (137). The addition of CTLA-4 blocking antibodies can partially lead to the rescue of the effective HBVspecific $\mathrm{CD}^{+} \mathrm{T}$ cell response in patients with persistent $\mathrm{HBV}$ infection (138).

The year 2013 marked a major breakthrough for cancer immunotherapy (139). Among effective cancer immunotherapies, blockage of the checkpoint inhibitors, CTLA-4 and PD-1, has shown the most promise, with many HCC patients increasingly benefiting from more treatment options and combinatorial immune checkpoint inhibitor blockade (140). For instance, blocking NKG2A potentiates tumor-infiltrating CD8 ${ }^{+}$T cell immunity but not NK cells (141). However, this immunosuppressive strategy is hindered by some immunological obstacles, thus resulting in only a minority of tumor patients achieving durable immune responses. Moreover, under certain conditions, $\mathrm{CD}^{+} \mathrm{T}$ cell exhaustion may occur in the absence of PD-1 upregulation (142). Therefore, other viable strategies for reversing $\mathrm{T}$ cell dysfunction are required to supplement immunotherapy in the context of liver disease.

Several types of parenchymal and nonparenchymal cells also exhibit immunomodulatory functions through their association with $\mathrm{T}$ cells in the liver. Therefore, the targeting of immune regulation between APCs or innate immune cells and dysfunctional $\mathrm{T}$ cells is expected to have a positive effect on the treatment of liver disease. Evidence suggests that the impairment of DC function is associated with exhausted $\mathrm{T}$ cell responses and that $\mathrm{CD} 40$-mediated $\mathrm{mDC}$ activation rescues intrahepatic anti-HBV $\mathrm{CD}^{+} \mathrm{T}$ cells from $\mathrm{PD}-1$-mediated exhaustion (143).

In patients with HCC, both the peripheral and blood DCs coexpress PD-1, while the intratumoral transfer of PD-1-deficient DCs elicits tumor-specific CD8 ${ }^{+} \mathrm{T}$ cell immune responses and restricts tumor growth (123). In chronic HBV infection, HBVinduced monocytes educate $\mathrm{NK}$ cells to produce IL-10 via the PDL1/PD-1 pathway, which then contributes to autologous $\mathrm{CD}^{+}$and $\mathrm{CD}^{+} \mathrm{T}$ cell inhibition (144). This suggests that

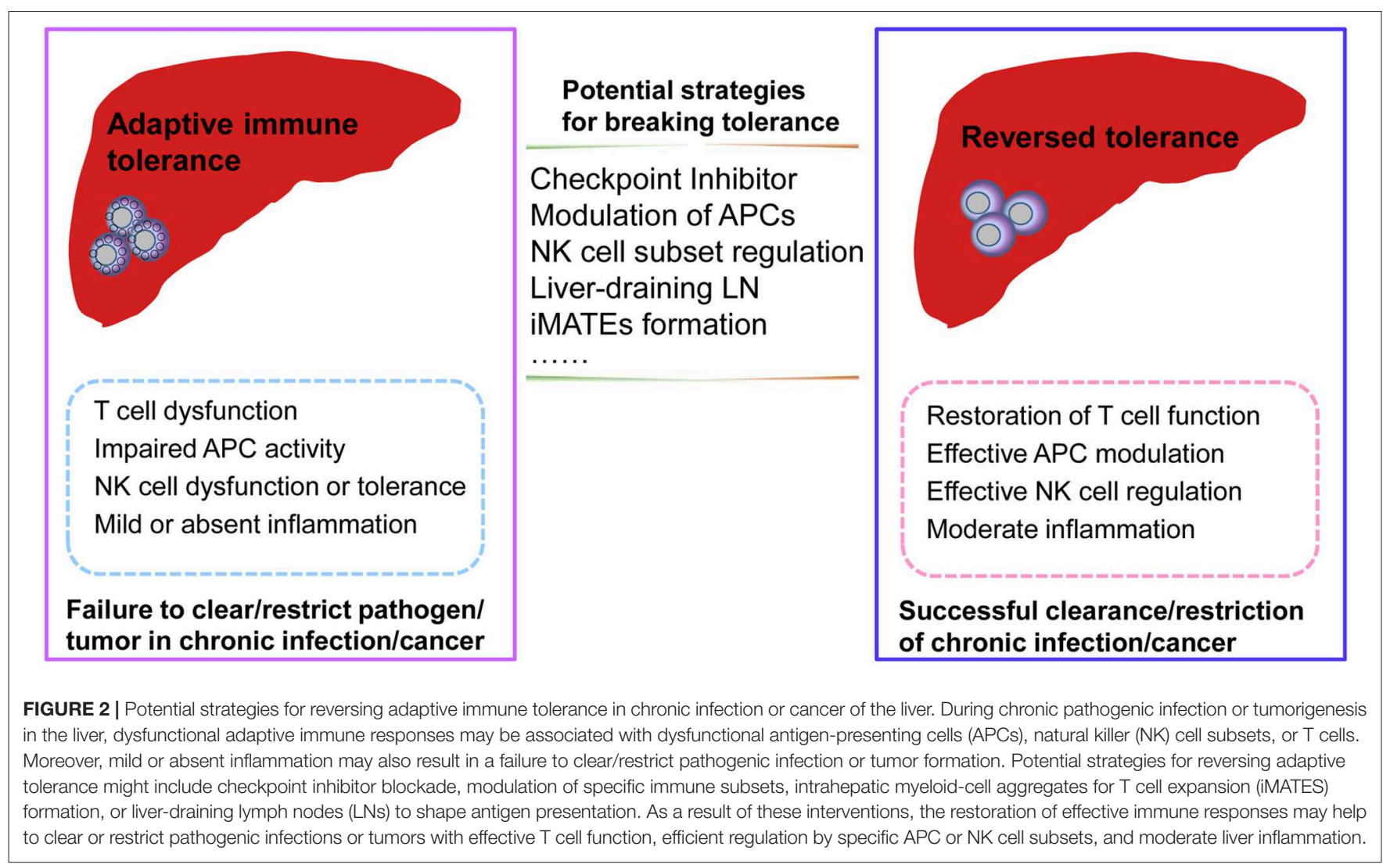


NK cells could be targeted for CHB therapy. Furthermore, the blockade of the checkpoint receptor, TIGIT, promotes NK cell-based tumor-specific T cell immunity, further highlighting the contribution of NK cells to the restoration of tumorspecific $\mathrm{CD}^{+} \mathrm{T}$ cell immune responses (145). In particular, the blockade of the inhibitory receptor NKG2A increases NK cell effector function and the associated anti-viral and anti-tumor immunity in chronic liver diseases, such as CHB infection and $\operatorname{HCC}(126,146)$.

Interestingly, the same anti-NKG2A blocking mAb was recently reported to enhance anti-tumor immune responses by unleashing both NK and T cell effector functions (147). In patients with $\mathrm{CHC}, \mathrm{TRAF}{ }^{1 \text { low }} \mathrm{HCV}$-specific $\mathrm{CD}^{+} \mathrm{T}$ cell function is restored through IL-7 plus 4-1BBL and PD-1 blockade treatment, indicating a promising immunotherapy for patients with CHC (148).

\section{CONCLUDING REMARKS}

The liver has developed various mechanisms for the induction and maintenance of immune tolerance. Hepatic immunotolerance is associated with the presence of dysfunctional $\mathrm{T}$ cells, and the processes of clonal deletion, anergy and exhaustion, dysfunctional regulatory cells, and altered liver inflammatory processes. During chronic liver disease, this tolerogenic state prevents the mounting of an effective adaptive immune cell response against pathogens or tumor cells.

In addition to the immunotherapeutic strategies employed to overcome tolerance in liver disease, several approaches have been developed to reverse T cell dysfunction. For instance, Knolle and colleagues found that even in chronic viral infection, antigenactivated intrahepatic $\mathrm{CD}^{+} \mathrm{T}$ cell proliferation was induced by intrahepatic myeloid-cell aggregates for $\mathrm{T}$ cell expansion (iMATEs) without causing liver immune pathology via the TLR pathway (149). Although it has not been determined whether

\section{REFERENCES}

1. Calne RY, Sells RA, Pena JR, Davis DR, Millard PR, Herbertson BM, et al. Induction of immunological tolerance by porcine liver allografts. Nature. (1969) 223:472-6. doi: 10.1038/223472a0

2. Qian S, Demetris AJ, Murase N, Rao AS, Fung JJ, Starzl TE. Murine liver allograft transplantation: tolerance and donor cell chimerism. Hepatology. (1994) 19:916-24. doi: 10.1002/hep. 1840190418

3. Loduca PA, Hoffman BE, Herzog RW. Hepatic gene transfer as a means of tolerance induction to transgene products. Curr Gene Ther. (2009) 9:104-14. doi: $10.2174 / 156652309787909490$

4. Luth S, Huber S, Schramm C, Buch T, Zander S, Stadelmann C, et al. Ectopic expression of neural autoantigen in mouse liver suppresses experimental autoimmune neuroinflammation by inducing antigen-specific Tregs. J Clin Invest. (2008) 118:3403-10. doi: 10.1172/JCI32132

5. Tiegs G, Lohse AW. Immune tolerance: what is unique about the liver. $J$ Autoimmun. (2010) 34:1-6. doi: 10.1016/j.jaut.2009.08.008

6. Gao B. Basic liver immunology. Cell Mol Immunol. (2016) 13:265-6. doi: $10.1038 / \mathrm{cmi} .2016 .09$
iMATEs have a similar structure to that of tertiary lymphoid tissue in local presentation and priming of $\mathrm{CD} 8^{+} \mathrm{T}$ cells, such findings may provide a new way to break $\mathrm{T}$ cell tolerance and induce effective anti-pathogen immune responses.

Furthermore, as secondary lymphoid organs, the liverdraining LNs help to shape immune responses in the liver and may play a role in reversing $\mathrm{T}$ cell dysfunction by modulating antigen presentation. Moreover, liver-resident NK cell subsets also inhibit $\mathrm{T}$ cell function via the PD-L1/PD-1 pathway, while the blockade of PD-L1 abrogates the suppression of $\mathrm{T}$ cell function (59). Recent advances in the field of innate immune cell biology, focusing on specific innate immune cell subsets and their different phenotypes and functions, will likely further clarify the regulatory mechanisms and molecular regulators needed to break liver-mediated immune tolerance and reverse adaptive immune cell dysfunction in liver disease. The questions of where and how hepatic immune subsets interact to generate dysfunctional $\mathrm{T}$ cells in the context of hepatic immunotolerance remain to be addressed. In summary, additional research is required to identify the innate immune subsets that are involved in inducing $\mathrm{T}$ cell dysfunction, the site of their interaction with $\mathrm{T}$ cells to render them dysfunctional, and the specific molecular mechanisms that are involved in this complex process (Figure 2).

\section{AUTHOR CONTRIBUTIONS}

$\mathrm{ZT}$ devised this manuscript. MZ wrote this manuscript. ZT and MZ revised the manuscript.

\section{FUNDING}

This work was supported by the Ministry of Science and Technology of China (2018YFA0507403), the Chinese Academy of Sciences (XDB29030201), and the National Natural Science Foundation of China (Grant Nos. 81788101, 81821001, 91542000, and 81771685).

7. Tian Z, Cao X, Chen Y, Lyu Q. Regional immunity in tissue homeostasis and diseases. Sci China Life Sci. (2016) 59:1205-9. doi: 10.1007/s11427-016-0351-y

8. Kubes P, Jenne C. Immune responses in the liver. Annu Rev Immunol. (2018) 36:247-77. doi: 10.1146/annurev-immunol-051116-052415

9. Qian S, Lu L, Fu F, Li Y, Li W, Starzl TE, et al. Apoptosis within spontaneously accepted mouse liver allografts: evidence for deletion of cytotoxic T cells and implications for tolerance induction. J Immunol. (1997) 158:4654-61.

10. Bertolino P, Trescol-Biemont MC, Rabourdin-Combe C. Hepatocytes induce functional activation of naive $\mathrm{CD}^{+} \mathrm{T}$ lymphocytes but fail to promote survival. Eur J Immunol. (1998) 28:221-36.

11. Crispe IN, Dao T, Klugewitz K, Mehal WZ, Metz DP. The liver as a site of T-cell apoptosis: graveyard, or killing field? Immunol Rev. (2000) 174:47-62. doi: 10.1034/j.1600-0528.2002.017412.x

12. Huang L, Soldevila G, Leeker M, Flavell R, Crispe IN. The liver eliminates $\mathrm{T}$ cells undergoing antigen-triggered apoptosis in vivo. Immunity. (1994) 1:741-9. doi: 10.1016/S1074-7613(94)80016-2

13. John B, Crispe IN. Passive and active mechanisms trap activated $\mathrm{CD}^{+} \mathrm{T}$ cells in the liver. J Immunol. (2004) 172:5222-9. doi: 10.4049/jimmunol.172.9.5222 
14. Holz LE, Benseler V, Bowen DG, Bouillet P, Strasser A, O'reilly L, et al. Intrahepatic murine CD8 T-cell activation associates with a distinct phenotype leading to Bim-dependent death. Gastroenterology. (2008) 135:989-97. doi: 10.1053/j.gastro.2008.05.078

15. Benseler V, Warren A, Vo M, Holz LE, Tay SS, Le Couteur DG, et al. Hepatocyte entry leads to degradation of autoreactive CD8 T cells. Proc Natl Acad Sci USA. (2011) 108:16735-40. doi: 10.1073/pnas.1112251108

16. Sierro F, Tay SS, Warren A, Le Couteur DG, Mccaughan GW, Bowen DG, et al. Suicidal emperipolesis: a process leading to cell-in-cell structures, $T$ cell clearance and immune homeostasis. Curr Mol Med. (2015) 15:819-27. doi: 10.2174/1566524015666151026102143

17. Knolle PA, Uhrig A, Hegenbarth S, Loser E, Schmitt E, Gerken G, et al. IL10 down-regulates $\mathrm{T}$ cell activation by antigen-presenting liver sinusoidal endothelial cells through decreased antigen uptake via the mannose receptor and lowered surface expression of accessory molecules. Clin Exp Immunol. (1998) 114:427-33. doi: 10.1046/j.1365-2249.1998.00713.x

18. Goubier A, Dubois B, Gheit H, Joubert G, Villard-Truc F, Asselin-Paturel C, et al. Plasmacytoid dendritic cells mediate oral tolerance. Immunity. (2008) 29:464-75. doi: 10.1016/j.immuni.2008.06.017

19. Knolle PA, Schmitt E, Jin S, Germann T, Duchmann R, Hegenbarth S, et al. Induction of cytokine production in naive $\mathrm{CD}^{+} \mathrm{T}$ cells by antigenpresenting murine liver sinusoidal endothelial cells but failure to induce differentiation toward Th1 cells. Gastroenterology. (1999) 116:1428-40. doi: 10.1016/S0016-5085(99)70508-1

20. Klugewitz K, Blumenthal-Barby F, Schrage A, Knolle PA, Hamann A, Crispe IN. Immunomodulatory effects of the liver: deletion of activated $\mathrm{CD}^{+}$effector cells and suppression of IFN-gamma-producing cells after intravenous protein immunization. J Immunol. (2002) 169:2407-13. doi: 10.4049/jimmunol.169.5.2407

21. Mclane LM, Abdel-Hakeem MS, Wherry EJ. CD8 T cell exhaustion during chronic viral infection and cancer. Annu Rev Immunol. (2019) 37:457-95. doi: 10.1146/annurev-immunol-041015-055318

22. Wherry EJ, Kurachi M. Molecular and cellular insights into T cell exhaustion. Nat Rev Immunol. (2015) 15:486-99. doi: 10.1038/nri3862

23. Amezquita RA, Kaech SM. Immunology: the chronicles of T-cell exhaustion. Nature. (2017) 543:190-1. doi: 10.1038/nature21508

24. Moskophidis D, Lechner F, Pircher H, Zinkernagel RM. Virus persistence in acutely infected immunocompetent mice by exhaustion of antiviral cytotoxic effector T cells. Nature. (1993) 362:758-61. doi: 10.1038/362758a0

25. Hashimoto M, Kamphorst AO, Im SJ, Kissick HT, Pillai RN, Ramalingam $\mathrm{SS}$, et al. CD8 T cell exhaustion in chronic infection and cancer: opportunities for interventions. Annu Rev Med. (2018) 69:301-18. doi: 10.1146/annurev-med-012017-043208

26. Tay SS, Wong YC, Mcdonald DM, Wood NA, Roediger B, Sierro F, et al. Antigen expression level threshold tunes the fate of CD8 T cells during primary hepatic immune responses. Proc Natl Acad Sci USA. (2014) 111:E2540-9. doi: 10.1073/pnas.1406674111

27. Myers LM, Tal MC, Torrez Dulgeroff LB, Carmody AB, Messer RJ, Gulati G, et al. A functional subset of $\mathrm{CD}^{+} \mathrm{T}$ cells during chronic exhaustion is defined by SIRPalpha expression. Nat Commun. (2019) 10:794. doi: 10.1038/s41467-019-08637-9

28. Horst AK, Neumann K, Diehl L, Tiegs G. Modulation of liver tolerance by conventional and nonconventional antigen-presenting cells and regulatory immune cells. Cell Mol Immunol. (2016) 13:277-92. doi: $10.1038 / \mathrm{cmi} .2015 .112$

29. Zeng Z, Li L, Chen $\mathrm{Y}$, Wei $\mathrm{H}$, Sun $\mathrm{R}$, Tian Z. Interferon-gamma facilitates hepatic antiviral $\mathrm{T}$ cell retention for the maintenance of liver-induced systemic tolerance. J Exp Med. (2016) 213:1079-93. doi: $10.1084 /$ jem. 20151218

30. Chyuan IT, Hsu PN. Tumor necrosis factor: the key to hepatitis B viral clearance. Cell Mol Immunol. (2018) 15:731-3. doi: 10.1038/cmi.2017.139

31. Saeidi A, Zandi K, Cheok YY, Saeidi H, Wong WF, Lee CYQ, et al. Tcell exhaustion in chronic infections: reversing the state of exhaustion and reinvigorating optimal protective immune responses. Front Immunol. (2018) 9:2569. doi: 10.3389/fimmu.2018.02569

32. Bowen DG, Zen M, Holz L, Davis T, Mccaughan GW, Bertolino P. The site of primary $\mathrm{T}$ cell activation is a determinant of the balance between intrahepatic tolerance and immunity. J Clin Invest. (2004) 114:701-12. doi: 10.1172/JCI200421593

33. Wong YC, Tay SS, Mccaughan GW, Bowen DG, Bertolino P. Immune outcomes in the liver: is CD8 T cell fate determined by the environment? J Hepatol. (2015) 63:1005-14. doi: 10.1016/j.jhep.2015.05.033

34. Herkel J, Jagemann B, Wiegard C, Lazaro JF, Lueth S, Kanzler S, et al. MHC class II-expressing hepatocytes function as antigen-presenting cells and activate specific CD4 T lymphocyutes. Hepatology. (2003) 37:1079-85. doi: 10.1053/jhep.2003.50191

35. Wiegard C, Wolint P, Frenzel C, Cheruti U, Schmitt E, Oxenius A, et al. Defective T helper response of hepatocyte-stimulated CD4 T cells impairs antiviral CD8 response and viral clearance. Gastroenterology. (2007) 133:2010-8. doi: 10.1053/j.gastro.2007.09.007

36. Le Guen V, Judor JP, Boeffard F, Gauttier V, Ferry N, Soulillou JP, et al. Alloantigen gene transfer to hepatocytes promotes tolerance to pancreatic islet graft by inducing $\mathrm{CD}^{+}$regulatory T cells. J Hepatol. (2017) 66:765-77. doi: 10.1016/j.jhep.2016.11.019

37. Zhang C, Wang XM, Li SR, Twelkmeyer T, Wang WH, Zhang SY, et al. NKG2A is a NK cell exhaustion checkpoint for HCV persistence. Nat Commun. (2019) 10:1507. doi: 10.1038/s41467-019-09212-y

38. Burghardt S, Claass B, Erhardt A, Karimi K, Tiegs G. Hepatocytes induce Foxp $^{+}{ }^{+}$regulatory T cells by Notch signaling. J Leukoc Biol. (2014) 96:571-7. doi: 10.1189/jlb.2AB0613-342RR

39. Ghislat G, Lawrence T. Autophagy in dendritic cells. Cell Mol Immunol. (2018) 15:944-52. doi: 10.1038/cmi.2018.2

40. Tiberio L, Del Prete A, Schioppa T, Sozio F, Bosisio D, Sozzani S. Chemokine and chemotactic signals in dendritic cell migration. Cell Mol Immunol. (2018) 15:346-52. doi: 10.1038/s41423-018-0005-3

41. Xia S, Guo Z, Xu X, Yi H, Wang Q, Cao X. Hepatic microenvironment programs hematopoietic progenitor differentiation into regulatory dendritic cells, maintaining liver tolerance. Blood. (2008) 112:3175-85. doi: 10.1182/blood-2008-05-159921

42. Morelli AE, Thomson AW. Tolerogenic dendritic cells and the quest for transplant tolerance. Nat Rev Immunol. (2007) 7:610-21. doi: $10.1038 /$ nri2132

43. Obregon C, Kumar R, Pascual MA, Vassalli G, Golshayan D. Update on dendritic cell-induced immunological and clinical tolerance. Front Immunol. (2017) 8:1514. doi: 10.3389/fimmu.2017.01514

44. Thomson AW, Humar A, Lakkis FG, Metes DM. Regulatory dendritic cells for promotion of liver transplant operational tolerance: rationale for a clinical trial and accompanying mechanistic studies. Hum Immunol. (2018) 79:314-21. doi: 10.1016/j.humimm.2017.10.017

45. Bamboat ZM, Stableford JA, Plitas G, Burt BM, Nguyen HM, Welles AP, et al. Human liver dendritic cells promote T cell hyporesponsiveness. J Immunol. (2009) 182:1901-11. doi: 10.4049/jimmunol.0803404

46. Jenne CN, Kubes P. Immune surveillance by the liver. Nat Immunol. (2013) 14:996-1006. doi: 10.1038/ni.2691

47. Xu L, Yin W, Sun R, Wei H, Tian Z. Kupffer cell-derived IL-10 plays a key role in maintaining humoral immune tolerance in hepatitis B virus-persistent mice. Hepatology. (2014) 59:443-52. doi: 10.1002/hep.26668

48. You Q, Cheng L, Kedl RM, Ju C. Mechanism of $\mathrm{T}$ cell tolerance induction by murine hepatic Kupffer cells. Hepatology. (2008) 48:978-90. doi: 10.1002/hep.22395

49. Li Y, Kim BG, Qian S, Letterio JJ, Fung JJ, Lu L, et al. Hepatic stellate cells inhibit T cells through active TGF-betal from a cell surfacebound latent TGF-beta1/GARP complex. J Immunol. (2015) 195:2648-56. doi: 10.4049/jimmunol.1500139

50. Charles R, Chou HS, Wang L, Fung JJ, Lu L, Qian S. Human hepatic stellate cells inhibit T-cell response through B7-H1 pathway. Transplantation. (2013) 96:17-24. doi: 10.1097/TP.0b013e318294caae

51. Limmer A, Ohl J, Kurts C, Ljunggren HG, Reiss Y, Groettrup M, et al. Efficient presentation of exogenous antigen by liver endothelial cells to CD8 ${ }^{+}$ T cells results in antigen-specific T-cell tolerance. Nat Med. (2000) 6:1348-54. doi: $10.1038 / 82161$

52. Peng H, Jiang X, Chen Y, Sojka DK, Wei H, Gao X, et al. Liver-resident NK cells confer adaptive immunity in skin-contact inflammation. J Clin Invest. (2013) 123:1444-56. doi: 10.1172/JCI66381 
53. Male V. Liver-resident NK cells: the human factor. Trends Immunol. (2017) 38:307-9. doi: 10.1016/j.it.2017.02.008

54. Peng H, Sun R. Liver-resident NK cells and their potential functions. Cell Mol Immunol. (2017). doi: 10.1038/cmi.2017.72. [Epub ahead of print].

55. Cuff AO, Robertson FP, Stegmann KA, Pallett LJ, Maini MK, Davidson BR, et al. Eomeshi NK cells in human liver are long-lived and do not recirculate but can be replenished from the circulation. J Immunol. (2016) 197:4283-91. doi: 10.4049/jimmunol.1601424

56. He Y, Tian Z. NK cell education via nonclassical MHC and non-MHC ligands. Cell Mol Immunol. (2017) 14:321-30. doi: 10.1038/cmi.2016.26

57. Zheng M, Sun H, Tian Z. Natural killer cells in liver diseases. Front Med. (2018) 12:269-79. doi: 10.1007/s11684-018-0621-4

58. Zheng M, Sun R, Wei H, Tian Z. NK cells help induce anti-hepatitis B virus $\mathrm{CD}^{+} \mathrm{T}$ cell immunity in mice. J Immunol. (2016) 196:4122-31. doi: 10.4049/jimmunol.1500846

59. Zhou J, Peng H, Li K, Qu K, Wang B, Wu Y, et al. Liver-resident NK cells control antiviral activity of hepatic $\mathrm{T}$ cells via the PD-1-PD-L1 Axis. Immunity. (2019) 50, 403-17 e404. doi: 10.1016/j.immuni.2018.12.024

60. Liu Y, Zheng J, Liu Y, Wen L, Huang L, Xiang Z, et al. Uncompromised NK cell activation is essential for virus-specific CTL activity during acute influenza virus infection. Cell Mol Immunol. (2018) 15:827-37. doi: $10.1038 / \mathrm{cmi} .2017 .10$

61. Cook KD, Whitmire JK. The depletion of NK cells prevents T cell exhaustion to efficiently control disseminating virus infection. J Immunol. (2013) 190:641-9. doi: 10.4049/jimmunol.1202448

62. Lassen MG, Lukens JR, Dolina JS, Brown MG, Hahn YS. Intrahepatic IL10 maintains $\mathrm{NKG}_{2} \mathrm{~A}^{+}$Ly49- liver NK cells in a functionally hyporesponsive state. J Immunol. (2010) 184:2693-701. doi: 10.4049/jimmunol.0901362

63. Peppa D, Gill US, Reynolds G, Easom NJ, Pallett LJ, Schurich A, et al. Upregulation of a death receptor renders antiviral T cells susceptible to NK cellmediated deletion. J Exp Med. (2013) 210:99-114. doi: 10.1084/jem.20121172

64. Male V, Stegmann KA, Easom NJ, Maini MK. Natural killer cells in liver disease. Semin Liver Dis. (2017) 37:198-209. doi: 10.1055/s-0037-1603946

65. Boni C, Lampertico P, Talamona L, Giuberti T, Invernizzi F, Barili V, et al. Natural killer cell phenotype modulation and natural killer/T-cell interplay in nucleos(t)ide analogue-treated hepatitis e antigen-negative patients with chronic hepatitis B. Hepatology. (2015) 62:1697-709. doi: 10.1002/hep.28155

66. Trottein F, Paget C. Natural killer $T$ cells and mucosal-associated invariant $\mathrm{T}$ cells in lung infections. Front Immunol. (2018) 9:1750. doi: 10.3389/fimmu.2018.01750

67. Lan P, Fan Y, Zhao Y, Lou X, Monsour HP, Zhang X, et al. TNF superfamily receptor OX40 triggers invariant NKT cell pyroptosis and liver injury. J Clin Invest. (2017) 127:2222-34. doi: 10.1172/JCI91075

68. Santodomingo-Garzon T, Han J, Le T, Yang Y, Swain MG. Natural killer $\mathrm{T}$ cells regulate the homing of chemokine $\mathrm{CXC}$ receptor 3-positive regulatory $\mathrm{T}$ cells to the liver in mice. Hepatology. (2009) 49:1267-76. doi: 10.1002/hep.22761

69. Wahl C, Bochtler P, Schirmbeck R, Reimann J. Type I IFN-producing CD4 Valpha14i NKT cells facilitate priming of IL-10-producing CD8 T cells by hepatocytes. J Immunol. (2007) 178:2083-93. doi: 10.4049/jimmunol.178.4.2083

70. Salio M, Silk JD, Jones EY, Cerundolo V. Biology of CD1- and MR1-restricted T cells. Annu Rev Immunol. (2014) 32:323-66. doi: 10.1146/annurev-immunol-032713-120243

71. Bertoletti A, Gehring AJ. Immune therapeutic strategies in chronic hepatitis B virus infection: virus or inflammation control? PLoS Pathog. (2013) 9:e1003784. doi: 10.1371/journal.ppat.1003784

72. Kurioka A, Walker LJ, Klenerman P, Willberg CB. MAIT cells: new guardians of the liver. Clin Transl Immunol. (2016) 5:e98. doi: 10.1038/cti.2016.51

73. Barathan M, Mohamed R, Vadivelu J, Chang LY, Saeidi A, Yong YK, et al. Peripheral loss of $\mathrm{CD}^{+} \mathrm{CD}^{+} 161^{++}$TCRValpha7.2 $2^{+}$mucosal-associated invariant $\mathrm{T}$ cells in chronic hepatitis C virus-infected patients. Eur J Clin Invest. (2016) 46:170-80. doi: 10.1111/eci.12581

74. Dias J, Hengst J, Parrot T, Leeansyah E, Lunemann S, Malone DFG, et al. Chronic hepatitis delta virus infection leads to functional impairment and severe loss of MAIT cells. J Hepatol. (2019) 71:301-12. doi: 10.1016/j.jhep.2019.04.009
75. Duan M, Goswami S, Shi JY, Wu LJ, Wang XY, Ma JQ, et al. Activated and exhausted MAIT cells foster disease progression and indicate poor outcome in hepatocellular carcinoma. Clin Cancer Res. (2019) 25:3304-16. doi: 10.1158/1078-0432.CCR-18-3040

76. Cottagiri M, Nyandjo M, Stephens M, Mantilla JJ, Saito H, Mackay IR, et al. In drug-induced, immune-mediated hepatitis, interleukin33 reduces hepatitis and improves survival independently and as a consequence of FoxP3 ${ }^{+}$T-cell activity. Cell Mol Immunol. (2018) 16:706-17. doi: 10.1038/s41423-018-0087-y

77. Penaloza-Macmaster P, Kamphorst AO, Wieland A, Araki K, Iyer SS, West $\mathrm{EE}$, et al. Interplay between regulatory $\mathrm{T}$ cells and PD-1 in modulating $\mathrm{T}$ cell exhaustion and viral control during chronic LCMV infection. J Exp Med. (2014) 211:1905-18. doi: 10.1084/jem.20132577

78. Franzese O, Kennedy PT, Gehring AJ, Gotto J, Williams R, Maini MK, et al. Modulation of the $\mathrm{CD} 8^{+}-\mathrm{T}$-cell response by $\mathrm{CD}^{+}{ }^{+} \mathrm{CD} 25^{+}$regulatory $\mathrm{T}$ cells in patients with hepatitis B virus infection. J Virol. (2005) 79:3322-8. doi: 10.1128/JVI.79.6.3322-3328.2005

79. Xu D, Fu J, Jin L, Zhang H, Zhou C, Zou Z, et al. Circulating and liver resident $\mathrm{CD} 4^{+} \mathrm{CD} 25^{+}$regulatory $\mathrm{T}$ cells actively influence the antiviral immune response and disease progression in patients with hepatitis B. J Immunol. (2006) 177:739-47. doi: 10.4049/jimmunol.177.1.739

80. Tan A, Koh S, Bertoletti A. Immune response in hepatitis B virus infection. Cold Spring Harb Perspect Med. (2015) 5:a021428. doi: $10.1101 /$ cshperspect.a021428

81. Bertoletti A, Ferrari C. Adaptive immunity in HBV infection. J Hepatol. (2016) 64:S71-S83. doi: 10.1016/j.jhep.2016.01.026

82. Maruyama T, Schodel F, Iino S, Koike K, Yasuda K, Peterson $\mathrm{D}$, et al. Distinguishing between acute and symptomatic chronic hepatitis-B virus-infection. Gastroenterology. (1994) 106:1006-15. doi: 10.1016/0016-5085(94)90761-7

83. Gerlich WH. Medical virology of hepatitis B: how it began and where we are now. Virol J. (2013) 10:239. doi: 10.1186/1743-422X-10-239

84. Vanwolleghem T, Hou J, Van Oord G, Andeweg AC, Osterhaus AD, Pas SD, et al. Re-evaluation of hepatitis B virus clinical phases by systems biology identifies unappreciated roles for the innate immune response and B cells. Hepatology. (2015) 62:87-100. doi: 10.1002/hep.27805

85. Le Bert N, Salimzadeh L, Gill US, Dutertre CA, Fachetti F, Tan A, et al. Comparative characterization of B cells specific for HBV nucleocapsid and envelope proteins in patients with chronic hepatitis B. J Hepatol. (2019). doi: 10.1016/j.jhep.2019.07.015. [Epub ahead of print].

86. Klein I, Crispe IN. Complete differentiation of $\mathrm{CD}^{+} \mathrm{T}$ cells activated locally within the transplanted liver. J Exp Med. (2006) 203:437-47. doi: 10.1084/jem.20051775

87. Belz GT, Altman JD, Doherty PC. Characteristics of virus-specific $\mathrm{CD}^{+} \mathrm{T}$ cells in the liver during the control and resolution phases of influenza pneumonia. Proc Natl Acad Sci USA. (1998) 95:13812-7. doi: $10.1073 /$ pnas.95.23.13812

88. Tanaka M, Iwakiri Y. The hepatic lymphatic vascular system: structure, function, markers, and lymphangiogenesis. Cell Mol Gastroenterol Hepatol. (2016) 2:733-49. doi: 10.1016/j.jcmgh.2016.09.002

89. Barbier L, Tay SS, Mcguffog C, Triccas JA, Mccaughan GW, Bowen DG, et al. Two lymph nodes draining the mouse liver are the preferential site of DC migration and T cell activation. J Hepatol. (2012) 57:352-8. doi: 10.1016/j.jhep.2012.03.023

90. Zheng M, Yu J, Tian Z. Characterization of the liver-draining lymph nodes in mice and their role in mounting regional immunity to HBV. Cell $\mathrm{Mol}$ Immunol. (2013) 10:143-50. doi: 10.1038/cmi.2012.59

91. Yu J, Chen Y, Wu Y, Ye L, Lian Z, Wei H, et al. The differential organogenesis and functionality of two liver-draining lymph nodes in mice. J Autoimmun. (2017) 84:109-21. doi: 10.1016/j.jaut.2017.08.005

92. Braden B, Faust D, Ignee A, Schreiber D, Hirche T, Dietrich CF. Clinical relevance of perihepatic lymphadenopathy in acute and chronic liver disease. J Clin Gastroenterol. (2008) 42:931-6. doi: 10.1097/MCG.0b013e31811edcf7

93. Hikita H, Nakagawa H, Tateishi R, Masuzaki R, Enooku K, Yoshida H, et al. Perihepatic lymph node enlargement is a negative predictor of liver cancer development in chronic hepatitis C patients. J Gastroenterol. (2013) 48:366-73. doi: 10.1007/s00535-012-0635-7 
94. Boor PPC, Bosma BM, Tran KTC, Van Der Laan LJW, Hagenaars $\mathrm{H}$, Jnm IJ, et al. Characterization of antigen-presenting cell subsets in human liver-draining lymph nodes. Front Immunol. (2019) 10:441. doi: 10.3389/fimmu.2019.00441

95. Liang TJ. Hepatitis B: the virus and disease. Hepatology. (2009) 49:S13-21. doi: 10.1002/hep.22881

96. Gehring AJ, Haniffa M, Kennedy PT, Ho ZZ, Boni C, Shin A, et al. Mobilizing monocytes to cross-present circulating viral antigen in chronic infection. $J$ Clin Invest. (2013) 123:3766-76. doi: 10.1172/JCI66043

97. Lanford RE, Guerra B, Chavez D, Giavedoni L, Hodara VL, Brasky KM, et al. GS-9620, an oral agonist of Toll-like receptor-7, induces prolonged suppression of hepatitis B virus in chronically infected chimpanzees. Gastroenterology. (2013) 144, 1508-17, 1517 e1501-10. doi: 10.1053/j.gastro.2013.02.003

98. Boni C, Vecchi A, Rossi M, Laccabue D, Giuberti T, Alfieri A, et al. TLR7 agonist increases responses of hepatitis B virus-specific $\mathrm{T}$ cells and natural killer cells in patients with chronic hepatitis B treated with nucleos(T)Ide analogues. Gastroenterology. (2018) 154, 1764-77 e1767. doi: 10.1053/j.gastro.2018.01.030

99. Ferrari C, Penna A, Bertoletti A, Valli A, Antoni AD, Giuberti T, et al. Cellular immune response to hepatitis B virus-encoded antigens in acute and chronic hepatitis B virus infection. J Immunol. (1990) 145:3442-9.

100. Schulte I, Hitziger T, Giugliano S, Timm J, Gold H, Heinemann FM, et al. Characterization of $\mathrm{CD}^{+} \mathrm{T}$-cell response in acute and resolved hepatitis $\mathrm{A}$ virus infection. J Hepatol. (2011) 54:201-8. doi: 10.1016/j.jhep.2010.07.010

101. Holz L, Rehermann B. T cell responses in hepatitis C virus infection: historical overview and goals for future research. Antiviral Res. (2015) 114:96-105. doi: 10.1016/j.antiviral.2014.11.009

102. Thimme R, Wieland S, Steiger C, Ghrayeb J, Reimann KA, Purcell RH, et al. $\mathrm{CD}^{+} \mathrm{T}$ cells mediate viral clearance and disease pathogenesis during acute hepatitis B virus infection. J Virol. (2003) 77:68-76. doi: 10.1128/JVI.77.1.68-76.2003

103. Penna A, Chisari FV, Bertoletti A, Missale G, Fowler P, Giuberti T, et al. Cytotoxic T lymphocytes recognize an HLA-A2-restricted epitope within the hepatitis B virus nucleocapsid antigen. J Exp Med. (1991) 174:1565-70. doi: 10.1084/jem.174.6.1565

104. Maini MK, Boni C, Ogg GS, King AS, Reignat S, Lee CK, et al. Direct ex vivo analysis of hepatitis $\mathrm{B}$ virus-specific $\mathrm{CD} 8^{+} \mathrm{T}$ cells associated with the control of infection. Gastroenterology. (1999) 117:1386-96. doi: 10.1016/S0016-5085(99)70289-1

105. Boni C, Fisicaro P, Valdatta C, Amadei B, Di Vincenzo P, Giuberti $\mathrm{T}$, et al. Characterization of hepatitis B virus (HBV)-specific T-cell dysfunction in chronic HBV infection. J Virol. (2007) 81:4215-25. doi: 10.1128/JVI.02844-06

106. Schuch A, Salimi Alizei E, Heim K, Wieland D, Kiraithe MM, Kemming J, et al. Phenotypic and functional differences of $\mathrm{HBV}$ core-specific versus $\mathrm{HBV}$ polymerase-specific $\mathrm{CD} 8^{+} \mathrm{T}$ cells in chronically $\mathrm{HBV}$-infected patients with low viral load. Gut. (2019) 68:905-15. doi: 10.1136/gutjnl-2018-316641

107. Spangenberg HC, Viazov S, Kersting N, Neumann-Haefelin C, Mckinney $\mathrm{D}$, Roggendorf $\mathrm{M}$, et al. Intrahepatic $\mathrm{CD}^{+}$T-cell failure during chronic hepatitis C virus infection. Hepatology. (2005) 42:828-37. doi: 10.1002/hep.20856

108. Zhu D, Liu L, Yang D, Fu S, Bian Y, Sun Z, et al. Clearing persistent extracellular antigen of hepatitis B virus: an immunomodulatory strategy to reverse tolerance for an effective therapeutic vaccination. J Immunol. (2016) 196:3079-87. doi: 10.4049/jimmunol.1502061

109. Park JJ, Wong DK, Wahed AS, Lee WM, Feld JJ, Terrault N, et al. Hepatitis B virus-specific and global T-cell dysfunction in chronic hepatitis B. Gastroenterology. (2016) 150:684-95 e685. doi: 10.1053/j.gastro.2015. 11.050

110. Mcmahan RH, Golden-Mason L, Nishimura MI, Mcmahon BJ, Kemper M, Allen TM, et al. Tim-3 expression on PD-1 ${ }^{+}$HCV-specific human CTLs is associated with viral persistence, and its blockade restores hepatocyte-directed in vitro cytotoxicity. J Clin Invest. (2010) 120:4546-57. doi: 10.1172/JCI43127

111. Bertolino P, Bowen DG. Malaria and the liver: immunological hide-andseek or subversion of immunity from within? Front Microbiol. (2015) 6:41. doi: $10.3389 /$ fmicb. 2015.00041
112. Wykes MN, Horne-Debets JM, Leow CY, Karunarathne DS Malaria drives T cells to exhaustion. Front Microbiol. (2014) 5:249. doi: $10.3389 /$ fmicb.2014.00249

113. Taylor MD, Van Der Werf N, Maizels RM. T cells in helminth infection: the regulators and the regulated. Trends Immunol. (2012) 33:181-9. doi: 10.1016/j.it.2012.01.001

114. Chuah C, Jones MK, Burke ML, Mcmanus DP, Gobert GN. Cellular and chemokine-mediated regulation in schistosome-induced hepatic pathology. Trends Parasitol. (2014) 30:141-50. doi: 10.1016/j.pt.2013.12.009

115. Smith P, Walsh CM, Mangan NE, Fallon RE, Sayers JR, Mckenzie AN, et al. Schistosoma mansoni worms induce anergy of $\mathrm{T}$ cells via selective up-regulation of programmed death ligand 1 on macrophages. J Immunol. (2004) 173:1240-8. doi: 10.4049/jimmunol.173.2.1240

116. Zheng C, Zheng L, Yoo JK, Guo H, Zhang Y, Guo X, et al. Landscape of infiltrating $\mathrm{T}$ cells in liver cancer revealed by single-cell sequencing. Cell. (2017) 169:1342-56 e1316. doi: 10.1016/j.cell.2017.05.035

117. Sen DR, Kaminski J, Barnitz RA, Kurachi M, Gerdemann U, Yates KB, et al. The epigenetic landscape of T cell exhaustion. Science. (2016) 354:1165-9. doi: 10.1126/science.aae0491

118. Zhou G, Sprengers D, Boor PPC, Doukas M, Schutz H, Mancham S, et al. Antibodies against immune checkpoint molecules restore functions of tumor-infiltrating T cells in hepatocellular carcinomas. Gastroenterology. (2017) 153:1107-19 e1110. doi: 10.1053/j.gastro.2017.06.017

119. Kim HD, Song GW, Park S, Jung MK, Kim MH, Kang HJ, et al. Association between expression level of PD1 by tumor-infiltrating $\mathrm{CD} 8^{+} \mathrm{T}$ cells and features of hepatocellular carcinoma. Gastroenterology. (2018) 155:1936-50 e1917. doi: 10.1053/j.gastro.2018.08.030

120. Ji J, Yin $\mathrm{Y}, \mathrm{Ju} \mathrm{H}, \mathrm{Xu} \mathrm{X}$, Liu W, Fu Q, et al. Long non-coding RNA Lnc-Tim3 exacerbates CD8 T cell exhaustion via binding to Tim-3 and inducing nuclear translocation of Bat3 in HCC. Cell Death Dis. (2018) 9:478. doi: 10.1038/s41419-018-0528-7

121. Li F, Li N, Sang J, Fan X, Deng $H$, Zhang X, et al. Highly elevated soluble Tim-3 levels correlate with increased hepatocellular carcinoma risk and poor survival of hepatocellular carcinoma patients in chronic hepatitis B virus infection. Cancer Manag Res. (2018) 10:941-51. doi: 10.2147/CMAR.S162478

122. Martin-Sierra C, Martins R, Laranjeira P, Abrantes AM, Oliveira RC, Tralhao JG, et al. Functional impairment of circulating fcepsilonri ${ }^{+}$monocytes and myeloid dendritic cells in hepatocellular carcinoma and cholangiocarcinoma patients. Cytometry B Clin Cytom. (2019). doi: 10.1002/cyt o.b.21777. [Epub ahead of print].

123. Lim TS, Chew V, Sieow JL, Goh S, Yeong JP, Soon AL, et al. PD-1 expression on dendritic cells suppresses $\mathrm{CD} 8^{+} \mathrm{T}$ cell function and antitumor immunity. Oncoimmunology. (2016) 5:e1085146. doi: 10.1080/2162402X.2015.1085146

124. Wu K, Kryczek I, Chen L, Zou W, Welling TH. Kupffer cell suppression of $\mathrm{CD}^{+} \mathrm{T}$ cells in human hepatocellular carcinoma is mediated by B7-H1/programmed death-1 interactions. Cancer Res. (2009) 69:8067-75. doi: 10.1158/0008-5472.CAN-09-0901

125. Cong J, Wang X, Zheng X, Wang D, Fu B, Sun R, et al. Dysfunction of natural killer cells by FBP1-induced inhibition of glycolysis during lung cancer progression. Cell Metab. (2018) 28:243-55 e245. doi: 10.1016/j.cmet.2018.06.021

126. Sun C, Xu J, Huang Q, Huang $M$, Wen $H$, Zhang C, et al. High NKG2A expression contributes to NK cell exhaustion and predicts a poor prognosis of patients with liver cancer. Oncoimmunology. (2017) 6:e1264562. doi: 10.1080/2162402X.2016.1264562

127. Sun H, Xu J, Huang Q, Huang M, Li K, Qu K, et al. Reduced CD160 expression contributes to impaired NK-cell function and poor clinical outcomes in patients with HCC. Cancer Res. (2018) 78:6581-93. doi: 10.1158/0008-5472.CAN-18-1049

128. Sun H, Huang Q, Huang M, Wen H, Lin R, Zheng M, et al. Human CD96 correlates to natural killer cell exhaustion and predicts the prognosis of human hepatocellular carcinoma. Hepatology. (2019) 70:16883. doi: 10.1002/hep.30347

129. Zhang QF, Yin WW, Xia Y, Yi YY, He QF, Wang X, et al. Liver-infiltrating CD11b(-)CD27(-) NK subsets account for NK-cell dysfunction in patients with hepatocellular carcinoma and are associated with tumor progression. Cell Mol Immunol. (2017) 14:819-29. doi: 10.1038/cmi.2016.28 
130. Wang R, Xu A, Zhang X, Wu J, Freywald A, Xu J, et al. Novel exosometargeted T-cell-based vaccine counteracts T-cell anergy and converts CTL exhaustion in chronic infection via CD40L signaling through the mTORC1 pathway. Cell Mol Immunol. (2017) 14:529-45. doi: 10.1038/cmi.2016.23

131. Kah J, Koh S, Volz T, Ceccarello E, Allweiss L, Lutgehetmann M, et al. Lymphocytes transiently expressing virus-specific $\mathrm{T}$ cell receptors reduce hepatitis B virus infection. J Clin Invest. (2017) 127:3177-88. doi: 10.1172/JCI93024

132. Qasim W, Brunetto M, Gehring AJ, Xue SA, Schurich A, Khakpoor A, et al. Immunotherapy of HCC metastases with autologous T cell receptor redirected T cells, targeting HBsAg in a liver transplant patient. J Hepatol. (2015) 62:486-91. doi: 10.1016/j.jhep.2014.10.001

133. Ilan Y, Nagler A, Adler R, Naparstek E, Or R, Slavin S, et al. Adoptive transfer of immunity to hepatitis B virus after $\mathrm{T}$ cell-depleted allogeneic bone marrow transplantation. Hepatology. (1993) 18:246-52. doi: 10.1016/0270-9139(93)90003-6

134. Lau GK, Lok AS, Liang RH, Lai CL, Chiu EK, Lau YL, et al. Clearance of hepatitis B surface antigen after bone marrow transplantation: role of adoptive immunity transfer. Hepatology. (1997) 25:1497-501. doi: 10.1002/hep.510250631

135. Zeng Z, Kong X, Li F, Wei H, Sun R, Tian Z. IL-12-based vaccination therapy reverses liver-induced systemic tolerance in a mouse model of hepatitis B virus carrier. J Immunol. (2013) 191:4184-93. doi: 10.4049/jimmunol.1203449

136. Bengsch B, Martin B, Thimme R. Restoration of HBV-specific CD8 ${ }^{+} \mathrm{T}$ cell function by PD-1 blockade in inactive carrier patients is linked to $\mathrm{T}$ cell differentiation. J Hepatol. (2014) 61:1212-9. doi: 10.1016/j.jhep.2014.07.005

137. Schurich A, Pallett LJ, Lubowiecki M, Singh HD, Gill US, Kennedy PT, et al. The third signal cytokine IL-12 rescues the anti-viral function of exhausted HBV-specific CD8 T cells. PLoS Pathog. (2013) 9:e1003208. doi: 10.1371/journal.ppat.1003208

138. Schurich A, Khanna P, Lopes AR, Han KJ, Peppa D, Micco L, et al. Role of the coinhibitory receptor cytotoxic $\mathrm{T}$ lymphocyte antigen-4 on apoptosisProne CD8 T cells in persistent hepatitis B virus infection. Hepatology. (2011) 53:1494-503. doi: 10.1002/hep.24249

139. Couzin-Frankel J. Breakthrough of the year 2013. Cancer Immunother Sci. (2013) 342:1432-3. doi: 10.1126/science.342.6165.1432

140. Kudo M. Targeted and immune therapies for hepatocellular carcinoma: predictions for 2019 and beyond. World J Gastroenterol. (2019) 25:789-807. doi: 10.3748/wjg.v25.i7.789

141. Van Montfoort N, Borst L, Korrer MJ, Sluijter M, Marijt KA, Santegoets SJ, et al. NKG2A blockade potentiates CD8 T cell immunity induced by cancer vaccines. Cell. (2018) 175:1744-55 e1715. doi: 10.1016/j.cell.2018.10.028
142. Odorizzi PM, Pauken KE, Paley MA, Sharpe A, Wherry EJ. Genetic absence of PD-1 promotes accumulation of terminally differentiated exhausted CD8 ${ }^{+}$T cells. J Exp Med. (2015) 212:1125-37. doi: 10.1084/jem. 20142237

143. Isogawa M, Chung J, Murata Y, Kakimi K, Chisari FV. CD40 activation rescues antiviral $\mathrm{CD}^{+} \mathrm{T}$ cells from $\mathrm{PD}-1-$ mediated exhaustion. PLoS Pathog. (2013) 9:e1003490. doi: 10.1371/journal.ppat.1003490

144. Li H, Zhai N, Wang Z, Song H, Yang Y, Cui A, et al. Regulatory NK cells mediated between immunosuppressive monocytes and dysfunctional T cells in chronic HBV infection. Gut. (2018) 67:2035-44. doi: 10.1136/gutjnl-2017-314098

145. Zhang Q, Bi J, Zheng X, Chen Y, Wang H, Wu W, et al. Blockade of the checkpoint receptor TIGIT prevents NK cell exhaustion and elicits potent anti-tumor immunity. Nat Immunol. (2018) 19:723-32. doi: 10.1038/s41590-018-0132-0

146. Li F, Wei H, Wei H, Gao Y, Xu L, Yin W, et al. Blocking the natural killer cell inhibitory receptor NKG2A increases activity of human natural killer cells and clears hepatitis B virus infection in mice. Gastroenterology. (2013) 144:392-401. doi: 10.1053/j.gastro.2012.10.039

147. Andre P, Denis C, Soulas C, Bourbon-Caillet C, Lopez J, Arnoux T, et al. Anti-NKG2A mAb is a checkpoint inhibitor that promotes anti-tumor immunity by unleashing both T and NK cells. Cell. (2018) 175:1731-43 e1713. doi: 10.1016/j.cell.2018.10.014

148. Moreno-Cubero E, Subira D, Sanz-De-Villalobos E, Parra-Cid T, Madejon A, Miquel J, et al. According to Hepatitis C Virus (HCV) infection stage, interleukin-7 plus 4-1BB triggering alone or combined with PD-1 blockade increases TRAF1(low) HCV-specific CD8 ${ }^{+}$cell reactivity. J Virol. (2018) 92. doi: 10.1128/JVI.01443-17

149. Huang LR, Wohlleber D, Reisinger F, Jenne CN, Cheng RL, Abdullah Z, et al. Intrahepatic myeloid-cell aggregates enable local proliferation of $\mathrm{CD}^{+} \mathrm{T}$ cells and successful immunotherapy against chronic viral liver infection. Nat Immunol. (2013) 14:574-83. doi: 10.1038/ni.2573

Conflict of Interest: The authors declare that the research was conducted in the absence of any commercial or financial relationships that could be construed as a potential conflict of interest.

Copyright (c) 2019 Zheng and Tian. This is an open-access article distributed under the terms of the Creative Commons Attribution License (CC BY). The use, distribution or reproduction in other forums is permitted, provided the original author(s) and the copyright owner(s) are credited and that the original publication in this journal is cited, in accordance with accepted academic practice. No use, distribution or reproduction is permitted which does not comply with these terms. 